\title{
Epidemiological typing of coagulase-negative staphylococci from nosocomial infections
}

\author{
C. GEARY, J. Z. JORDENS*, J. F. RICHARDSON†, D. M. HAWCROFT‡ and C. J. MITCHELL \\ Public Health Laboratory, Level 5, Sandringham Building, Leicester Royal Infirmary NHS Trust, Leicester LE1 \\ $5 W W$, *Public Health Laboratory, John Radcliffe Hospital, Headington, Oxford OX3 9DU, †Staphylococcus \\ Reference Unit, Central Public Health Laboratory, 61 Colindale Avenue, London NW9 5HT and $\ddagger$ School of \\ Applied Sciences, De Montfort University, The Gateway, Leicester LE1 $9 B H$
}

\begin{abstract}
Biotyping, antibiograms, bacteriophage typing, plasmid profile analysis and SDS-PAGE protein profiles were used to determine the relatedness of 44 Staphylococcus epidermidis and four $S$. haemolyticus isolates from 14 patients. A selection of these were further characterised by ribotyping. Biotyping classified the isolates into three major groups but was considered a poor strain marker. Although antibiograms classified the $S$. epidermidis isolates into 20 groups, some changes in the susceptibility patterns of related isolates from a single patient were demonstrated. Bacteriophage typing was the least discriminatory of the methods used. SDS-PAGE gave highly related patterns for the majority of $S$. epidermidis isolates. Plasmid profile analysis and ribotyping, with a minimum of two restriction endonucleases, were the most discriminatory methods for typing $S$. epidermidis. Nonetheless, some isolates from the same patient - probably representing a single strain - varied in plasmid profile indicating plasmid instability. One of six related isolates from a single patient lacked two bands from the ribotyping pattern of the other isolates. Although no single method proved entirely satisfactory on all occasions, the combination of typing methods was sufficient to provide evidence of the relatedness of $S$. epidermidis isolates from individual patients.
\end{abstract}

\section{Introduction}

The coagulase-negative staphylococci (CNS), particularly Staphylococcus epidermidis, are recognised as important nosocomial pathogens, especially in patients with prosthetic implant devices and immunocompromised patients [1]. Recent studies have also demonstrated CNS to be the most common blood culture isolates in neonatal intensive care units [2]. However, strains of $S$. epidermidis are also the most prevalent species on human skin surfaces, representing up to $90 \%$ of all staphylococci recovered [3]. Weinstein et al. [4], using both clinical and microbiological data obtained from a large series of blood culture isolates, were able to differentiate true pathogens from contaminants and considered $94 \%$ of the CNS to be clinically insignificant. Therefore, the isolation of CNS from blood cultures raises important questions both clinically and for the microbiology laboratory as to whether or not there is true clinical infection. Other species of CNS, especially S. haemolyticus, may also

Received 25 Jan. 1996; revised version accepted 30 July 1996.

Corresponding author: Dr C. Geary. cause clinical infection $[5,6]$. Strains of this species are often multiresistant and may exhibit reduced susceptibility to vancomycin [7].

Isolates of CNS can be readily identified to species level in diagnostic laboratories and it is rarely considered necessary to confirm the relatedness of uncommonly isolated species. However, repeated isolates of the ubiquitous $S$. epidermidis and the increasingly important $S$. haemolyticus from individual patients necessitate typing to confirm rapidly and reliably their relatedness. This is important not only to identify nosocomial outbreaks but also to distinguish true infection, represented by repeated isolation of the same strain, from contamination, indicated by the isolation of different strains. In certain patient categories it is also important to distinguish relapse of infection with the same strain from re-infection with a different strain.

Until recently the typing of CNS was based on traditional methods such as biotyping, antibiogram and bacteriophage (phage) typing. Serological methods were generally not sufficiently discriminatory [8]. Pfaller and Herwaldt [9] found the majority of $S$. 
epidermidis isolates to be contained within a few distinct biotypes. Instability of antibiotic resistance to $S$. epidermidis has been demonstrated [10] and a large proportion of nosocomial $S$. epidermidis isolates are resistant to multiple antibiotics, thus reducing the number of unique antibiograms [11]. Parisi [11] deemed phage typing of CNS as discouraging, as many strains of clinical importance were either not typable by the phage sets used, or gave long lytic patterns.

Because traditional methods were largely unsatisfactory, molecular methods - including SDS-PAGE, plasmid profiling and restriction endonuclease analysis of chromosomal DNA, with or without the use of a probe - have been tried [12-15]. However, these methods are comparative and, therefore, more suited to batch analyses. Although these techniques have been used with varying degrees of success, a recent review by Birnbaum et al. [16] concluded that 'no entirely satisfactory typing system currently exists for the CNS'. The aim of this study was to determine the relatedness of CNS isolates by the traditional typing methods of biotyping, antibiogram and phage typing in combination with the more recent molecular methods of plasmid profile analysis, protein profile analysis and ribotyping. The strains chosen were either representative of repeated or multiple CNS isolates from clinical infections, from episodes of uncertain clinical significance or selected on the basis of phenotypic variation.

\section{Materials and methods}

\section{Bacterial strains}

This study characterised 49 isolates of CNS, (numbered 301-349, Table 1) from 14 patients. Thirty-eight were from blood cultures, four from colonised intravenous catheters, three from prosthetic heart valves, two from urine and two from peritoneal dialysate fluid.

Strains were preserved at $-76^{\circ} \mathrm{C}$. For this study stored bacterial strains were subcultured on to freshly prepared blood agar (Oxoid), containing defibrinated horse blood $5 \%$ and incubated for $18-24 \mathrm{~h}$ at $37^{\circ} \mathrm{C}$. After checking for purity, a second subculture was prepared by taking six representative colonies from the original plate. Referral back to the original frozen culture minimised the possibility of both phenotypic and genotypic change during the study. Two unrelated $S$. haemolyticus isolates with similar biotypes to those from patient 6 were included for comparison of ribotyping patterns.

\section{Identification and biotyping}

The identification and biotypes of the staphylococcal isolates were determined by reference to the nine- and five-digit profile indices provided with the ATB 32
$\mathrm{Staph}^{\mathrm{TM}}$ identification system (bioMérieux) and the probabilistic identification scheme of Geary et al. [17] respectively.

\section{Antibiotic susceptibility testing}

The comparative disk diffusion method of Stokes and Waterworth [18], employing IsoSensitest agar (ISA, Oxoid) was used for all antibiotic susceptibility tests, with the exception of methicillin, in which case the media was ISA supplemented with $\mathrm{NaCl} 4 \%$; the control strain was $S$ aureus NCTC 6571. The antibiotics tested and disk content (Mast Diagnostics) were as follows: amikacin $30 \mu \mathrm{g}$, cefuroxime $30 \mu \mathrm{g}$, cephaloridine $30 \mu \mathrm{g}$, chloramphenicol $10 \mu \mathrm{g}$, ciprofloxacin $1 \mu \mathrm{g}$, clindamycin $2 \mu \mathrm{g}$, erythromycin $5 \mu \mathrm{g}$, fusidic acid $10 \mu \mathrm{g}$, gentamicin $10 \mu \mathrm{g}$, imipenem $10 \mu \mathrm{g}$, kanamycin $30 \mu \mathrm{g}$, methicillin $10 \mu \mathrm{g}$, mupirocin $5 \mu \mathrm{g}$, neomycin $10 \mu \mathrm{g}$, netilmicin $10 \mu \mathrm{g}$, penicillin $1 \mathrm{IU}$, rifampicin $2 \mu \mathrm{g}$, streptomycin $10 \mu \mathrm{g}$, sulphamethoxazole $100 \mu \mathrm{g}$, teicoplanin $30 \mu \mathrm{g}$, tetracycline $10 \mu \mathrm{g}$, tobramycin $10 \mu \mathrm{g}$, trimethoprim $2.5 \mu \mathrm{g}$, vancomycin $30 \mu \mathrm{g}$.

\section{Lactamase production}

Lactamase production was determined by the plate method of Park et al. [19].

\section{Bacteriophage (phage) typing}

The phage typing of CNS was done at the Staphylococcus Reference Unit, Colindale, as recommended by Richardson et al. 1992 [8]. Interpretation of the results was by the criteria used for S. aureus [20].

\section{Plasmid profile analysis}

The Brij-lysis method of Wilson et al. [21] with modifications suggested by Richardson et al. [8] was used. The supercoiled DNA ladder (Gibco BRL) was used as a molecular size marker and enabled the size of the plasmids to be determined.

\section{SDS-PAGE protein profile analysis}

Protein extracts of test isolates were made as described earlier [22] with Bernheimer's yeast diffusate medium [23]. Proteins precipitated with saturated ammonium sulphate $90 \% \mathrm{w} / \mathrm{v}$ were redissolved and purified by dialysis against glycine, $1 \%$. The supernate derived from this process was diluted four-fold in sample buffer and $20 \mu \mathrm{l}$ was loaded on to SDS-PAGE gels prepared as recommended by Laemmli [24]. Electrophoresis was performed in a BioRad mini Protean dual slab system at a constant $60 \mathrm{~V}$, until the dye front was just released from the end of the gel. The gels were stained for 15 min with Coomassie Brilliant Blue $0.1 \%$ $\mathrm{w} / \mathrm{v}$ and de-stained in methanol $40 \% \mathrm{v} / \mathrm{v}$, acetic acid $10 \% \mathrm{v} / \mathrm{v}$ for $15 \mathrm{~min}$ and then again in fresh de-stain 


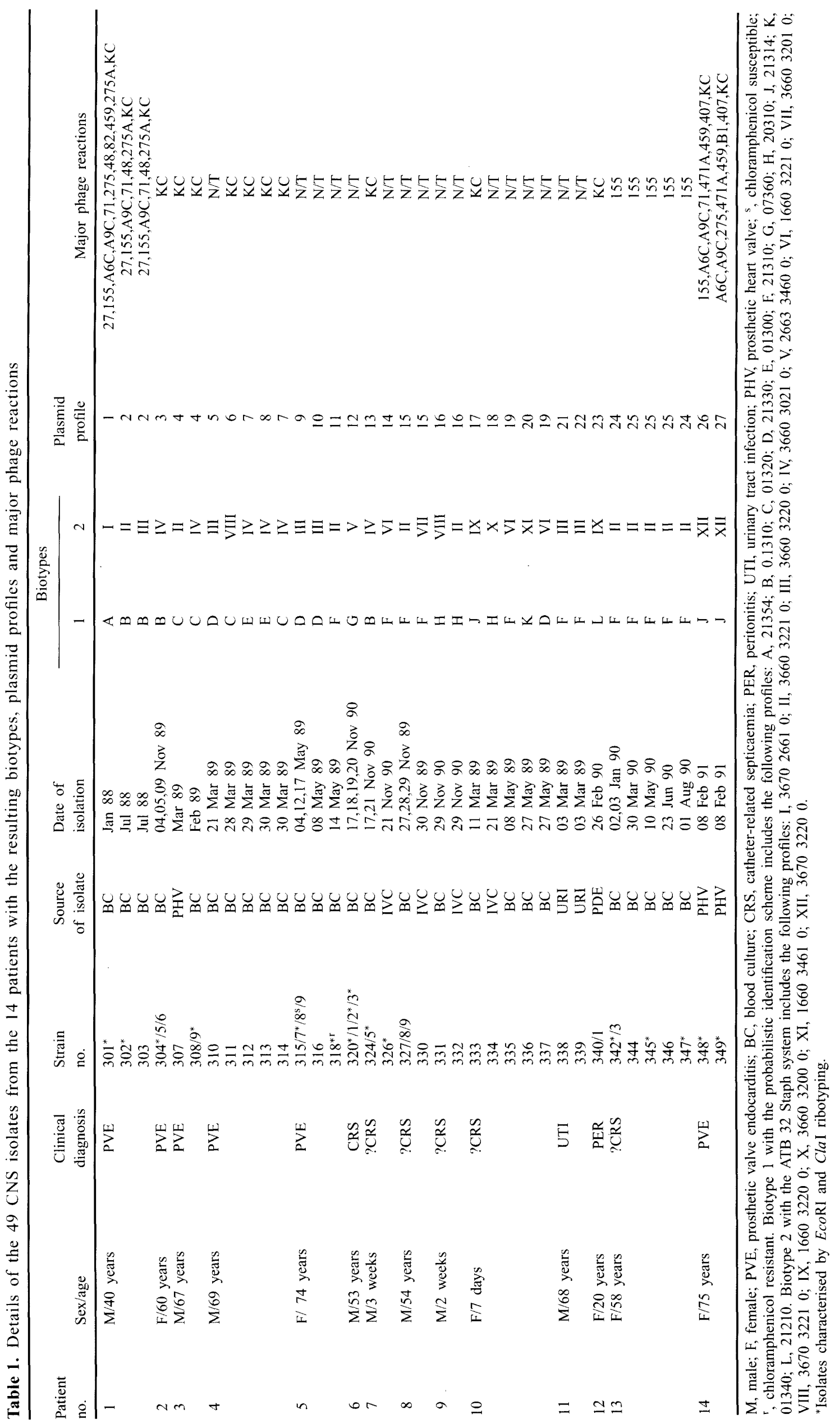


solution until the darkly stained protein bands were observed against a colourless background. To provide a permanent record the gel was dried by a vacuum drying system (Model 543, BioRad).

\section{Ribotyping}

A selection of isolates for which clarification of relatedness was sought were further characterised by ribotyping. Total cellular DNA was extracted by a modification of the method developed by Pitcher et al. [25] in which cells were pre-treated with $30 \mu \mathrm{l}$ of lysozyme $1.0 \mathrm{mg} / \mathrm{ml}$ and $10 \mu \mathrm{l}$ of lysostaphin $100 \mathrm{mg} /$ $\mathrm{ml}$ for $30 \mathrm{~min}$ at $37^{\circ} \mathrm{C}$. The probe was digoxigeninlabelled cDNA to $16 \mathrm{~S}+23 \mathrm{~S}$ ribosomal ribonucleic acid (rRNA) of Escherichia coli [26].

Southern blots of $5 \mu \mathrm{g}$ of ClaI: or $15 \mu \mathrm{g}$ of EcoRIdigested DNA separated on agarose gels $(0.7 \%$ in TBE buffer) were hybridised at $50^{\circ} \mathrm{C}$, and the membranes were washed under conditions of high stringency [26]. Bands of hybridisation were detected with the BluGene kit (Boehringer Mannheim Biochemica). Molecular size markers were digoxigeninlabelled DNA marker VI (Boehringer Mannheim Biochemia) and HindIII-digested DNA from Serratia fonticola [27].

\section{Results}

\section{Identification and biotyping}

Forty-four of the 49 isolates were identified as $S$. epidermidis. For these, the ATB scheme gave 10 biotypes and the probabilistic identification scheme nine (Table 1). Four isolates, all from patient 6, were $S$. haemolyticus with indistinguishable biotypes. The remaining isolate was identified as $S$. hominis.

\section{Antibiogram typing}

The antibiotic resistance patterns of the 44 isolates of $S$. epidermidis are given in Table 2. All 44 isolates were $\beta$-lactamase positive. There was little variation in the antibiotic resistance profiles. Fifteen of the 44 isolates were resistant to penicillin, trimethoprim, sulphamethoxazole, gentamicin, tobramycin and kanamycin, a further 18 isolates were resistant to five of these antimicrobial agents and five isolates were resistant to four agents. Two of the remaining six isolates (isolates 302 and 303 , patient 1) were distinctive in demonstrating resistance to rifampicin, penicillin, trimethoprim and sulphamethoxazole. Isolate 333 (patient 10) was resistant to streptomycin but sensitive to gentamicin and to tobramycin. Isolates 340 and 341 (patient 12) were resistant to penicillin and fusidic acid only. The remaining isolate (345), differed from the five other isolates from this patient in exhibiting a loss of resistance to kanamycin and gentamicin, associated with the instability of a large molecular mass plasmid. Phenotypes with both the dissociated and undissociated macrolide resistance were observed.

\section{Bacteriophage typing}

Thirty-eight of the isolates tested were either untypable by this phage set or lysed only by phage KC. Five of the 11 typable isolates, three from patient 1 and two from patient 14 exhibited long pattern lysis. The remaining six isolates, all from patient 13 , were lysed only by phage 155 .

\section{Plasmid profiles}

Plasmids were detected in all isolates of $S$. epidermidis and $S$. haemolyticus (Fig. 1). The isolate of S. hominis was plasmid-free.

Table 2. Antibiogram patterns of the $44 \mathrm{~S}$. epidermidis isolates

\begin{tabular}{|c|c|c|c|c|c|c|c|c|c|c|c|c|c|c|c|}
\hline Isolate (patient no.) & PE & TR & SX & $\mathrm{TE}$ & ER & KA & $\mathrm{GE}$ & TO & ST & RI & $\mathrm{CD}$ & FD & $\mathrm{CH}$ & MT & DR \\
\hline $301(1)$ & $\mathrm{R}$ & $\mathrm{R}$ & $\mathrm{R}$ & & & $\mathrm{R}$ & & & & & & & & & - \\
\hline $302 / 303$ (1) & $\mathrm{R}$ & $\mathrm{R}$ & $\mathrm{R}$ & & & & & & & $\mathrm{R}$ & & & & & - \\
\hline $304 / 305 / 306(2)$ & $\mathrm{R}$ & & $\mathrm{R}$ & $\mathrm{R}$ & $\mathrm{R}$ & $\mathrm{R}$ & $\mathrm{R}$ & $\mathrm{R}$ & & & & & & $\mathrm{R}$ & + \\
\hline $307 / 308 / 309$ & $\mathrm{R}$ & $\mathrm{R}$ & $\mathrm{R}$ & & $\mathrm{R}$ & $\mathrm{R}$ & $\mathrm{R}$ & $\mathrm{R}$ & & & $\mathrm{R}$ & & & & - \\
\hline $310(4)$ & $\mathrm{R}$ & $\mathrm{R}$ & $\mathrm{R}$ & & $\mathrm{R}$ & $\mathrm{R}$ & & & & & & & & & + \\
\hline $311 / 312 / 313 / 314$ (4) & $\mathrm{R}$ & $\mathrm{R}$ & $\mathrm{R}$ & $\mathrm{R}$ & $\mathrm{R}$ & $\mathrm{R}$ & $\mathrm{R}$ & $\mathrm{R}$ & & & $\mathrm{R}$ & & & $\mathrm{R}$ & - \\
\hline $315 / 316 / 317 / 318^{s / 319}(5)$ & $\mathrm{R}$ & $\mathrm{R}$ & $\mathrm{R}$ & & & $\mathrm{R}$ & $\mathrm{R}$ & & & & & & & & + \\
\hline $318^{\mathrm{r}}(5)$ & $\mathrm{R}$ & $\mathrm{R}$ & $\mathrm{R}$ & & & $\mathrm{R}$ & $\mathrm{R}$ & & & & & & $\mathrm{R}$ & & + \\
\hline $324 / 325(7)$ & $\mathrm{R}$ & $\mathrm{R}$ & $\mathrm{R}$ & & $\mathrm{R}$ & $\mathrm{R}$ & $\mathrm{R}$ & & & & & & & $\mathrm{R}$ & - \\
\hline $326(7)$ & $\mathrm{R}$ & & $\mathrm{R}$ & $\mathrm{R}$ & & $\mathrm{R}$ & $\mathrm{R}$ & $\mathrm{R}$ & & & & & $\mathrm{R}$ & $\mathrm{R}$ & - \\
\hline $327 / 328 / 329 / 330(8)$ & $\mathrm{R}$ & $\mathrm{R}$ & $\mathrm{R}$ & & $\mathrm{R}$ & $\mathrm{R}$ & $\mathrm{R}$ & $\mathrm{R}$ & & & & & & $\mathrm{R}$ & + \\
\hline $331 / 332(9)$ & $\mathrm{R}$ & $\mathrm{R}$ & $\mathrm{R}$ & & $\mathrm{R}$ & $\mathrm{R}$ & $\mathrm{R}$ & $\mathrm{R}$ & & & & & $\mathrm{R}$ & $\mathrm{R}$ & - \\
\hline $333(10)$ & $\mathrm{R}$ & $\mathrm{R}$ & $\mathrm{R}$ & & $\mathrm{R}$ & & & & $\mathrm{R}$ & & & & & $\mathrm{R}$ & + \\
\hline $334(10)$ & $\mathrm{R}$ & & & & & $\mathrm{R}$ & $\mathrm{R}$ & $\mathrm{R}$ & & & & & & $\mathrm{R}$ & - \\
\hline $335 / 337(10)$ & $\mathrm{R}$ & & $\mathrm{R}$ & & & $\mathrm{R}$ & $\mathrm{R}$ & $\mathrm{R}$ & & & & & $\mathrm{R}$ & & - \\
\hline $338 / 339$ (11) & $\mathrm{R}$ & $\mathrm{R}$ & $\mathrm{R}$ & & & $\mathrm{R}$ & $\mathrm{R}$ & $\mathrm{R}$ & & & & & & $\mathrm{R}$ & - \\
\hline $340 / 341(12)$ & $\mathrm{R}$ & & & & & & & & & & & $\mathrm{R}$ & & & - \\
\hline $342 / 343 / 344 / 346 / 347$ (13) & $\mathrm{R}$ & $\mathrm{R}$ & $\mathrm{R}$ & & $\mathrm{R}$ & $\mathrm{R}$ & $\mathrm{R}$ & & & & & & & $\mathrm{R}$ & + \\
\hline $345(13)$ & $\mathrm{R}$ & $\mathrm{R}$ & $\mathrm{R}$ & & $\mathrm{R}$ & & & & & & & & & $\mathrm{R}$ & + \\
\hline $348 / 349$ (14) & $\mathrm{R}$ & & $\mathrm{R}$ & & & $\mathrm{R}$ & $\mathrm{R}$ & & & & & & & & _- \\
\hline
\end{tabular}

PE, penicillin; TR, trimethoprim; SX, sulphamathoxazole; TE, tetracycline; ER, erythromycin; KA, kanamycin; GE, gentamicin; TO, tobramycin; ST, streptomycin; RI, rifampicin; CD, clindamycin; $\mathrm{CH}$, chloramphenicol; FD, fucidin; MT, methicillin; DR, dissociated resistance; $\mathrm{R}$, resistance; ${ }^{\mathrm{s}}$, chloramphenicol-sensitive cells; ${ }^{\mathrm{r}}$, chloramphenicol-resistant cells. 


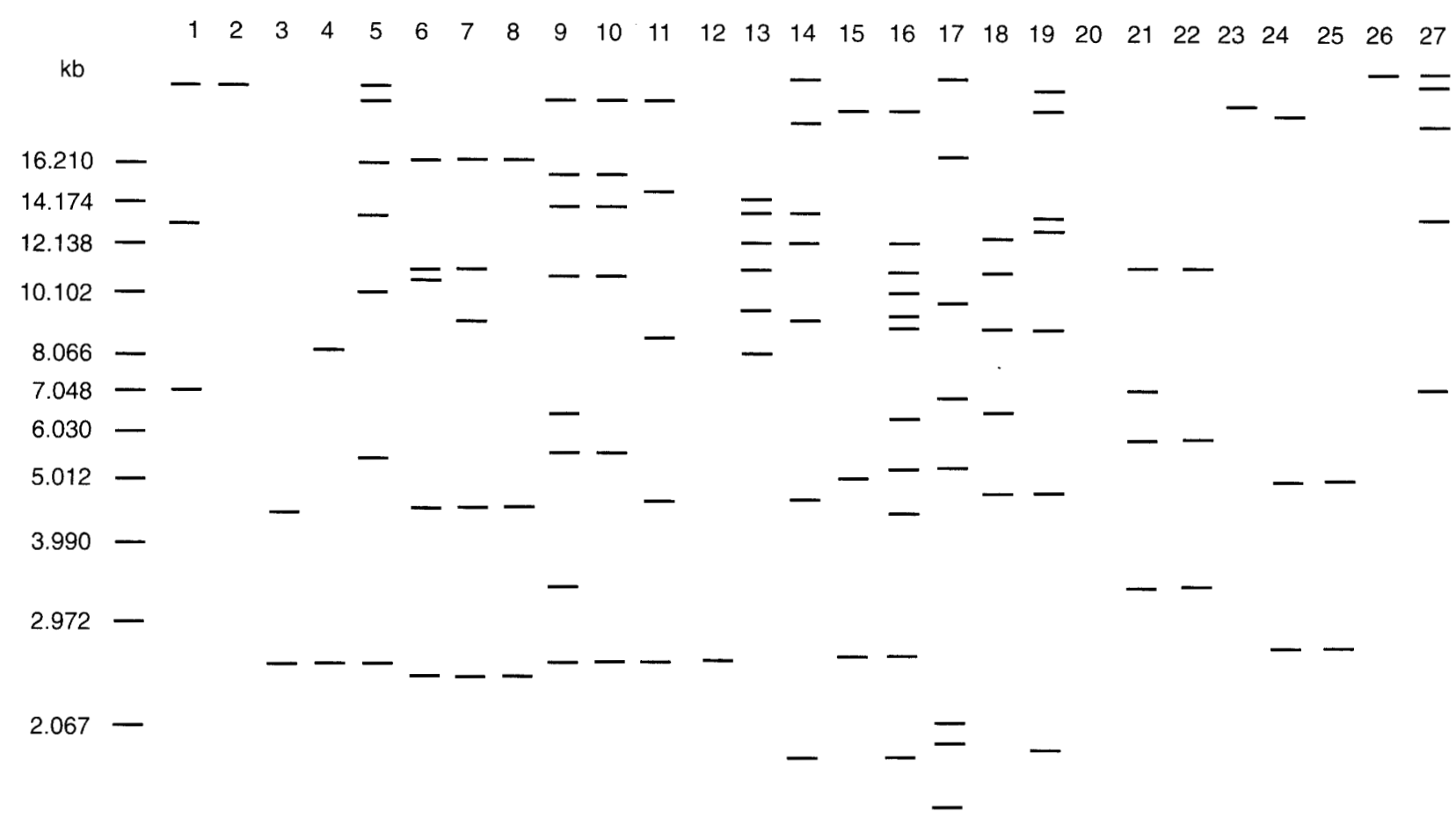

Fig. 1. Diagrammatic representation of the plasmid profiles detected amongst the study isolates. Profile numbers correspond to plasmid profiles in Table 1 .

\section{Protein profiles (SDS-PAGE)}

Distinct protein profiles were obtained from the 44 isolates of $S$. epidermidis. The number of bands varied from 25 to 40 . These were used for within-patient comparisons. Indistinct patterns were obtained for the four isolates of $S$. haemolyticus, possibly reflecting insufficient protein loading of the gel. The strain of $S$. hominis was not examined.

\section{Ribotyping}

Ribotyping patterns were obtained from digests with either Cla I or EcoRI. A total of 18 isolates was examined; 10 patterns comprising five-to-eight bands were obtained with $\mathrm{Cla}$ I and 12 patterns comprising 15-20 bands were obtained with EcoRI (Fig. 3).

\section{Assessment of relatedness of intra-patient isolates using the typing methods in combination}

Nineteen isolates were from five patients (1-5) with endocarditis in whom re-infection (with a different strain) or relapse with the same strain was suspected. Two different strains, indicating probable re-infection, were isolated from patients 1 and 4. Although the strains from patient 1 were distinct by all methods they demonstrated only minor differences in ribotype (Fig. 3). Alternatively, the first isolate from each patient may not have been clinically significant, whereas the latter ones were. Nosocomial cross-infection was suspected for the prosthetic valve endocarditis in patients 2 and 3, but the results indicated that although each patient was infected with a single strain, the infecting strain was distinct in each case. The five isolates from patient 5 were indistinguishable, with the exception of the chloramphenicol-resistant cells within 318 which were probably contaminants (Figs 2 and 3), indicating a relapse of infection. Although the two isolates from the prosthetic heart valves of patient 14 had very different colonial morphology with distinct phage types, plasmid types and SDS-PAGE protein profiles, their antibiograms, biotypes and ribotypes were identical. Similar colonial variants had been isolated previously from multiple blood cultures from this patient (although these were not typed) and may have represented either relapse of infection, possibly with two strains concurrently, or a single strain demonstrating significant changes in typing characteristics.

Twenty-four isolates were from six patients in whom catheter-related sepsis was suspected. The isolates from patients 6,8 and 9 all probably represented single strains as only minor differences in biotype (patients 8 and 9) were detected. The six isolates from patient 13 represented an unusual phage type - 155 with indistinguishable biotypes and SDS-PAGE profiles. However, minor differences were found in the antibiograms; five isolates were resistant to gentamicin and kanamycin, one was not (isolate 345, Table 2), correlating to the presence or absence of a 19-kb plasmid. Of three isolates from this patient selected for ribotyping, two (isolates 342 and 345) exhibited identical ribotypes when digested with either $\mathrm{Cla} \mathrm{I}$ or $E c o$ RI. The third (isolate 347 ), whilst showing identity when a Cla I digest was probed, differed in the loss of two bands when the EcoRI digests were probed (Fig. 3). Nonetheless, it was concluded that these isolates belonged to the same strain, supporting the 


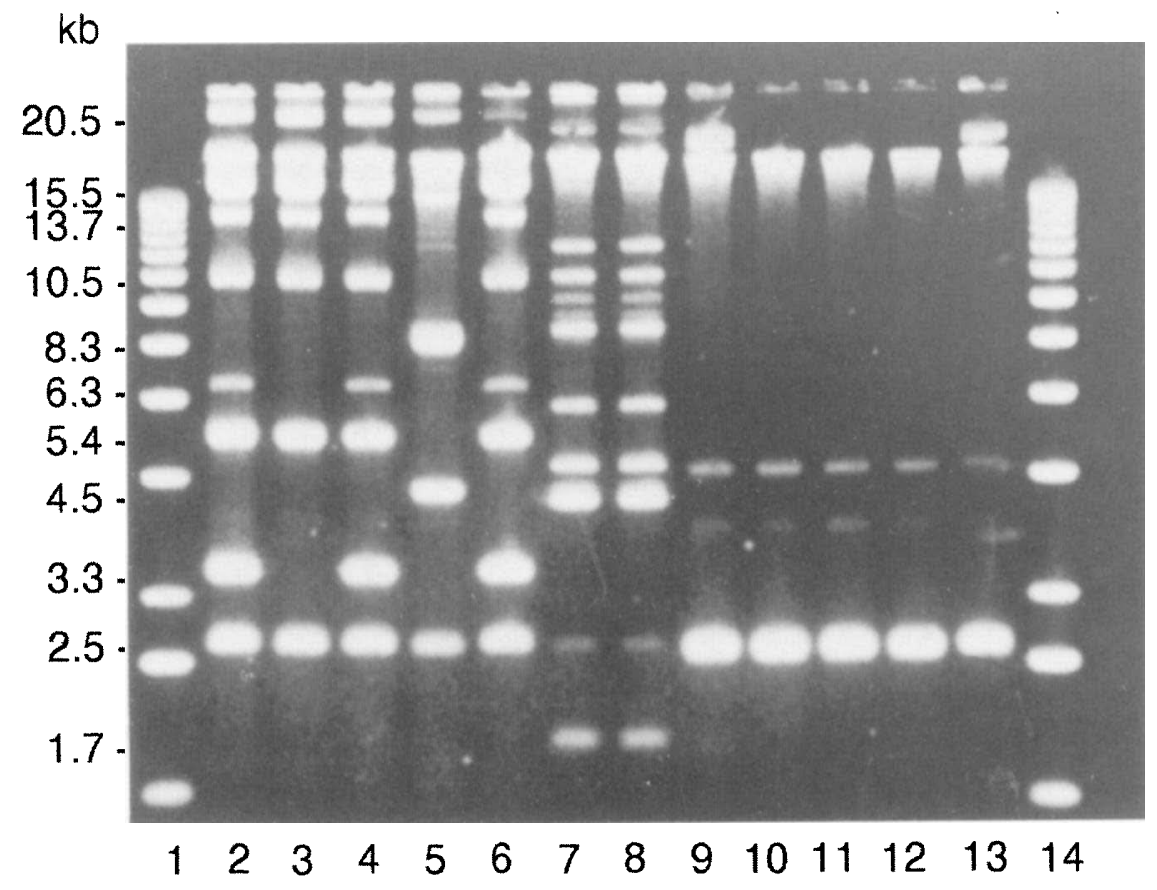

Fig. 2. Plasmid profiles of $S$. epidermidis strains derived from single colony subcultures. Lanes 1, 14, DNA molecular size marker; 2-4, 6, strains 315-7, 319 (patient 5); 5, chloramphenicol-resistant variant of isolate 318 (patient 5); 7, 8, strains 331/2 (patient 9); 9-13, strains 342/4/5/6/7 (patient 13).

clinical diagnosis. In contrast, the characterisation methods showed that isolates from patients 7 and 10 represented very different strains; the results therefore did not confirm the clinical diagnosis. Patients 11 and 12 suffered from a UTI and CAPD peritonitis, respectively. The two isolates from each of these patients had only minor differences and probably represented single, acute infections.

\section{Discussion}

The aim of this study was to use multiple typing methods, both phenotypic and genotypic, to determine the relatedness and thence clinical relevance of sets of isolates of CNS from a series of patients in which they were the only organisms isolated. None of the methods used - biotyping, antibiogram, phage typing, plasmid profiling, SDS-PAGE profiling and ribotyping - was ideal alone, but when results of these methods were considered in combination, it was thought that a realistic assessment of relatedness might be made. First, however, an assessment of the discrimination of each method was necessary.

The majority of strains of CNS from clinical infections are $S$. epidermidis; approximately $10 \%$ are $S$. haemolyticus. For any typing scheme to be useful epidemiologically, it must be able to recognise individual strains within these species.

With ATB $32 \mathrm{Staph}^{\mathrm{TM}}, 32$ of the 44 S. epidermidis isolates included in the present study were subdivided into three major biotypes, which showed only minor differences in profile. The remaining 12 isolates were subdivided into a further six biotypes. Similarly, the probabilistic scheme subdivided $28 \mathrm{~S}$. epidermidis strains into three biotypes. The remaining 16 isolates formed a further five biotypes. Clearly both identification schemes lack discriminatory power and are useful only for strains with an unusual biotype, as found in patient 9. The results from the ATB $32 \mathrm{Staph}^{\mathrm{TM}}$ were often discordant with those from the other methods, suggesting that it is unreliable as a strain marker.

Antibiograms can be useful markers for given strains of CNS, particularly where, as in this study, the local strains are resistant to various combinations of antibiotics. However, the treatment of a patient may influence both gain and loss of resistance markers encoded by plasmid DNA [28]. The isolates from patient 13 provided an example of plasmid instability. Furthermore, the same pattern of multi-resistance was common to many of the $S$. epidermidis strains examined in this study. Therefore, antibiogram typing is not sufficiently reliable or discriminatory to assess the relatedness of multiple isolates of S. epidermidis.

Bacteriophage typing of CNS has proved disappointing, mainly because of low typability rates, $<30 \%$ in some studies $[29,30]$. In the present study, phage typing proved useful on two occasions but, in general, was the least discriminatory of the methods used.

Plasmid profiling is the most widely used of the molecular methods used to characterise CNS and is regarded as complementary to antibiogram typing. It is 


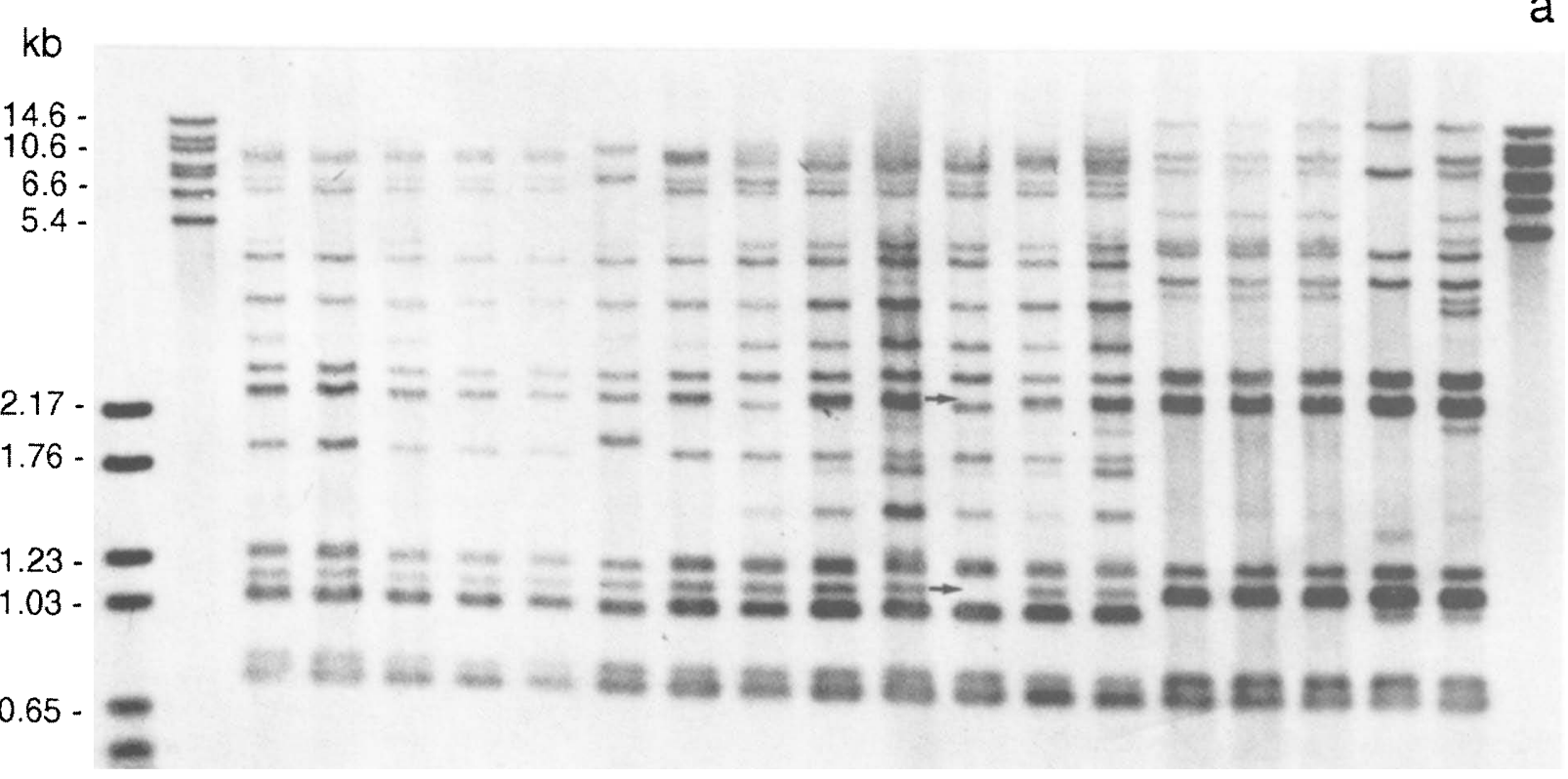

\section{$\begin{array}{llllllllllllllllllll}2 & 3 & 4 & 5 & 6 & 7 & 8 & 9 & 10 & 11 & 12 & 13 & 14 & 15 & 16 & 17 & 18 & 19 & 20 & 21\end{array}$}

b

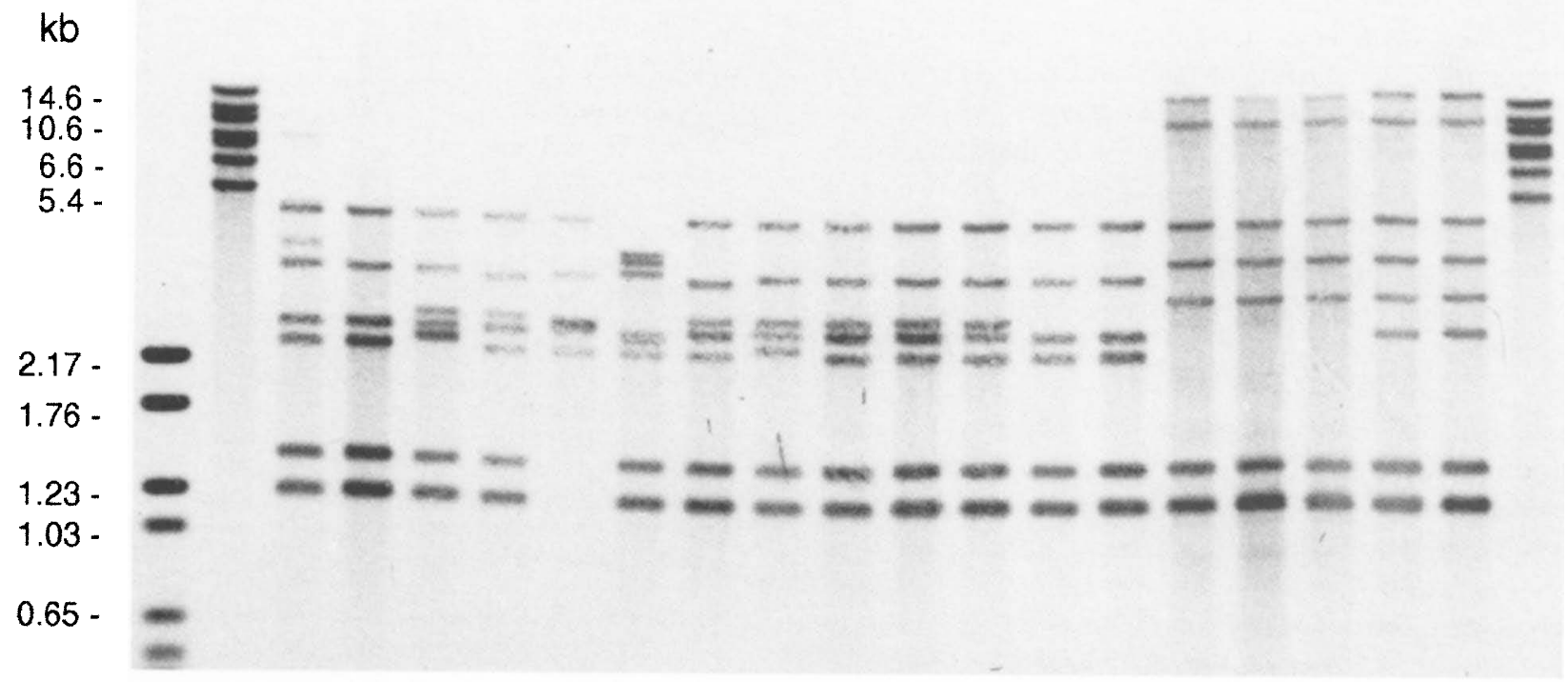

\section{$\begin{array}{llllllllllllllllllll}2 & 3 & 4 & 5 & 6 & 7 & 8 & 9 & 10 & 11 & 12 & 13 & 14 & 15 & 16 & 17 & 18 & 19 & 20 & 21\end{array}$}

Fig. 3. Ribotyping patterns of S. epidermidis (lanes 3-15) and S. haemolyticus (lanes 16-20) with: a, EcoRI; b, Cla I. Lanes 1, 2, 21, molecular size markers; 3, 4, isolates 301/2 (patient 1); 5, isolate 304 (patient 2); 6, isolate 309 (patient 3); 7, 8, isolates 317 and the chloramphenicol-resistant variant of 318 (patient 5); 9, 10, isolates 325/6 (patient 7); 11-13, isolates $342 / 5 / 7$ (patient 13) arrowed in lane 13 are the missing ribotyping bands derived with EcoRI; 14, 15, isolates 348/9 (patient 14); 16-18, isolates 320/2/3 (patient 6); 19, 20, two unrelated isolates of $S$. hemolyticus.

extremely useful when examining sensitive isolates containing cryptic plasmids, but is limited when isolates are plasmid-free. Additionally, when multiresistant strains are studied it is not possible, without time-consuming studies, to determine whether plasmids of the same apparent molecular mass encode the same resistance. With regard to the present study, the results from plasmid profiling were concordant with those from other methods according to the criteria of
Hartstein et al. [13]. They suggested three types of comparative assessment: (i) those isolates considered to be identical, which should have the same number of plasmids of the same molecular mass; (ii) those considered to be related, which should have a core of similar plasmids; these isolates should be investigated further; and (iii) unrelated isolates which should show multiple differences both in plasmid number and molecular mass. Although selection of multiple colo- 
nies for plasmid analysis is necessary to avoid loss of specific plasmids, as seen in this study with isolates from patient 13 , great care must be taken to avoid the inadvertent selection of mixed strains, as seen in the initial plasmid analysis of isolate 318 from patient 5 .

Thompson-Carter and Pennington [12] and Pennington et al. [31] suggested that although the SDS-PAGE profiles of isolates may be a useful adjunct to biochemical characterisation of a strain to species level, within a species there may be little easily observable difference in the profiles obtained. While the results of the present study largely concur with these observations, occasionally obvious differences in profiles were sufficiently useful to be an aid in the assignment of isolates to a specific strain; for example, isolates 333-337 from patient 10 .

Ribotyping has been used primarily as a means to speciate staphylococci [31,32]. However, De Buyser et al. [33] considered that, within $S$. epidermidis, ribotyping patterns were often sufficiently different to be used epidemiologically as well as taxonomically. However, it was necessary to digest with several enzymes separately. There is also evidence that, as with $S$. aureus, both the ribotype of clearly distinct strains may be indistinguishable and that several band differences, particularly when EcoRI digests are probed, may occur within isolates of the same strain [34]. Both phenomena were observed in this study. It would appear that although ribotyping is a useful adjunct to traditional typing methods, it may be higher up the hierarchical tree than some traditional typing techniques.

In conclusion, the combination of typing methods used in this study was sufficient to provide fairly conclusive evidence about the relatedness of patient isolates. The results strongly suggest that at least plasmid profiling and some form of chromosomal DNA analysis, e.g., ribotyping, are necessary to clarify the relationship of isolates of $S$. epidermidis that demonstrate similar typing characteristics when phenotypic typing methods are used. In agreement with Michelson et al. [10] and Etienne et al. [28] it was also shown that variations in strain characteristics of $S$. epidermidis may occur during the course of an infection, thus emphasising that experience is necessary when interpreting typing results. The use of a combination of typing methods necessary to discriminate within $S$. epidermidis may be beyond the remit of routine laboratories and hence will probably remain confined to reference laboratories.

\section{References}

1. Schumacher-Perdreau F. Clinical significance and laboratory diagnosis of coagulase-negative staphylococci. Clin Microbiol Newslett 1991; 13: 97-101.

2. Kacica MA, Horgan MJ, Preston KE, Lepow M, Venezia RA. Relatedness of coagulase-negative staphylococci causing bac- teremia in low-birth weight infants. Infect Control Hosp Epidemiol 1994; 15: 658-662.

3. Archer GL. Staphylococcus epidermidis and other coagulasenegative staphylococci. In: Mandell GL, Douglas GR, Bennett JE (eds) Principles and Practices of Infectious Diseases, 3rd ed. New York, Churchill Livingstone. 1990: 1511-1518.

4. Weinstein MP, Reller LB, Murphy JR, Lichtenstein KA. The clinical significance of positive blood cultures: a comprehensive analysis of 500 episodes of bacteremia and fungemia in adults. I. Laboratory and epidemiologic observations. Rev Infect Dis 1983; 5: 35-53.

5. Renaud F, Etienne J, Bertrand A et al. Molecular epidemiology of Staphylococcus haemolyticus strains isolated in an Albanian hospital. J Clin Microbiol 1991; 29: 1493-1497.

6. Low DE, Schmidt BK, Kirpalani HM et al. An endemic strain of Staphylococcus haemolyticus colonizing and causing bacteremia in neonatal intensive care unit patients. Pediatrics 1992; 89: 696-700.

7. Froggatt JW, Johnston JL, Galetto DW, Archer GL. Antimicrobial resistance in nosocomial isolates of Staphylococcus haemolyticus. Antimicrob Agents Chemother 1989; 33: $460-466$.

8. Richardson JF, Noble WC, Marples RR. Species identification and epidemiological typing of the staphylococci. In: Board RG, Jones D, Skinner FA (eds) Identification methods in applied and environmental microbiology. Society for Applied Bacteriology Technical Series no. 29. Oxford, Blackwell Scientific Publications. 1992: 193-219.

9. Pfaller MA, Herwaldt LA. Laboratory, clinical, and epidemiological aspects of coagulase-negative staphylococci. Clin Microbiol Rev 1988; 1: 281-299.

10. Mickelsen PA, Plorde JJ, Gordon KP et al. Instability of antibiotic resistance in a strain of Staphylococcus epidermidis isolated from an outbreak of prosthetic valve endocarditis. $J$ Infect Dis 1985; 152: 50-58.

11. Parisi JT. Coagulase-negative staphylococci and the epidemiological typing of Staphylococcus epidermidis. Microbiol Rev 1985; 49: $126-139$

12. Thomson-Carter FM, Pennington TH. Characterization of coagulase-negative staphylococci by sodium dodecyl sulfatepolyacrylamide gel electrophoresis and immunoblot analyses. J Clin Microbiol 1989; 27: 2199-2203.

13. Hartstein AI, Morthland VH, Rashad AL. Reproducibility of Staphylococcus epidermidis plasmid profiles. Diagn Microbiol Infect Dis 1991; 14: 275-280.

14. Izard NC, Hächler H, Grehn M, Kayser FH. Ribotyping of coagulase-negative staphylococci with special emphasis on intraspecific typing of Staphylococcus epidermidis. $J$ Clin Microbiol 1992; 30: 817-823.

15. Bialkowska-Hobrzanska $\mathrm{H}$, Jaskot $\mathrm{D}$, Hammerberg O. A method for DNA restriction endonuclease fingerprinting of coagulase-negative staphylococci. J Microbiol Methods 1990; 12: $41-49$.

16. Birnbaum D, Kelly M, Chow AW. Epidemiologic typing systems for coagulase-negative staphylococci. Infect Control Hosp Epidemiol 1991; 12: 319-326.

17. Geary C, Stevens M, Sneath PHA, Mitchell CJ. Construction of a database to identify Staphylococcus species. J Clin Pathol 1989; 42: 289-294.

18. Stokes EJ, Waterworth PM. Association of Clinical Pathologists Broadsheet No. 55, 1972 (revised).

19. Park CH, Lopez JS, Cook CB. Acidometric agar plate method for ampicillin susceptibility testing of Haemophilus influenzae. Antimicrob Agents Chemother 1978; 13: 318-320.

20. Dean BA, Williams REO, Hall F, Corse J. Phage typing of coagulase-negative staphylococci and micrococci. J Hyg 1973; 71: $261-270$.

21. Wilson CR, Totten PA, Baldwin JN. Rapid procedure for the detection of plasmids in Staphylococcus epidermidis. Appl Environ Microbiol 1978; 36: 368-374.

22. Geary C. Staphylococci: aspects of classification, pathogenesis and epidemiological typing, with special reference to Staphylococcus epidermidis. PhD Thesis, 1994: De Montfort University in collaboration with the Public Health Laboratory Service.

23. Bernheimer AW, Schwartz LL. Isolation and composition of staphylococcal alpha toxin. $J$ Gen Microbiol 1963; 30: 455-468.

24. Laemmli UK. Cleavage of structural proteins during the 
assembly of the head of bacteriophage T4. Nature 1970; 227: $680-685$.

25. Pitcher DG, Saunders NA, Owen RJ. Rapid extraction of bacterial genomic DNA with guanidium thiocyanate. Lett Appl Microbiol 1989; 8: $151-156$.

26. Jordens JZ, Leaves NI, Anderson EC, Slack MPE. Polymerase chain reaction-based strain characterization of noncapsulate Haemophilus influenzae. J Clin Microbiol 1993; 31: 2981-2987.

27. Grimont F, Grimont PAD. Ribosomal ribonucleic acid gene restriction patterns as potential taxonomic tools. Ann Inst Pasteur/Microbiol 1986; 137B: 165-175.

28. Etienne J, Renaud F, Bes M et al. Instability of characteristics amongst coagulase-negative staphylococci causing endocarditis. $J$ Med Microbiol 1990; 32: 115-122.

29. Ludlam HA, Noble WC, Marples RR, Bayston R, Phillips I. The epidemiology of peritonitis caused by coagulase-negative staphylococci in continuous ambulatory peritoneal dialysis. $J$ Med Microbiol 1989; 30: 167-174.
30. Dryden MS, Talsania HG, Martin S et al. Evaluation of methods for typing coagulase-negative staphylococci. $J \mathrm{Med}$ Microbiol 1992; 37: 109-117.

31. Pennington TH, Harker C, Thomson-Carter F. Identification of coagulase-negative staphylococci by using sodium dodecyl sulfate-polyacrylamide gel electrophoresis and rRNA restriction patterns. J Clin Microbiol 1991; 29: 390-392.

32. Bialkowska-Hobrzanska H, Harry V, Jaskot D, Hammerberg O. Typing of coagulase-negative staphylococci by Southern hybridization of chromosomal DNA fingerprints using a ribosomal RNA probe. Eur J Clin Microbiol Infect Dis 1990; 9: 588-594.

33. De-Buyser M-L, Morvan A, Grimont F, el-Sohl N. Characterization of Staphylococcus species by ribosomal RNA gene restriction patterns. J Gen Microbiol 1989; 135: 989-999.

34. Cookson BD, Stapleton P, Ludlum H. Ribotyping of coagulasenegative staphylococci. $J$ Med Microbiol 1992; 36: 414-419. 